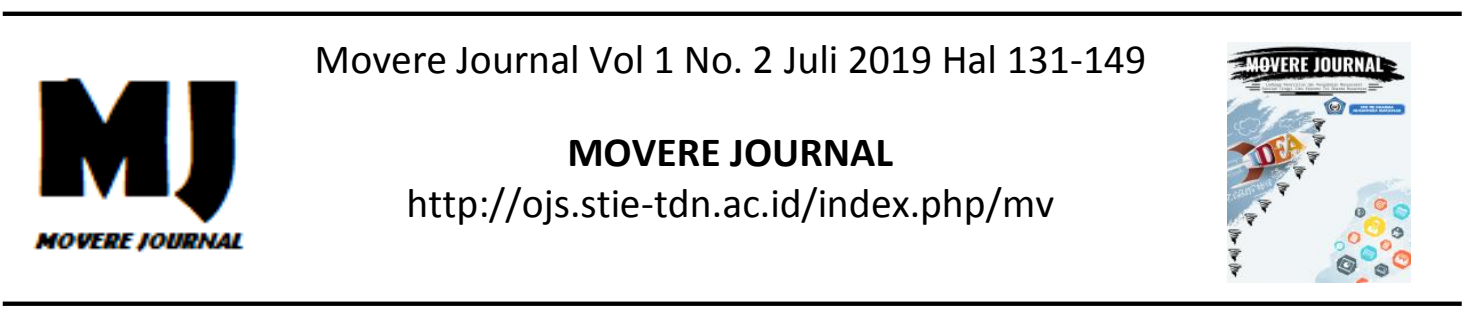

\title{
PENENTUAN RASIO-RASIO KEUANGAN YANG BERPENGARUH TERHADAP KESEHATAN KEUANGAN PERUSAHAAN ASURANSI UMUM DI INDONESIA
}

\author{
Andi Indra Martini \\ STIE Muhammadiyah Maтuju
}

\begin{abstract}
Abstrak : The purpose of this research is to determine financial ratios that affected financial appropriateness for the general insurance firms in Indonesia. The research is undertaken in Jakarta at Indonesian General Insurance Association office (AAUI). This research used survey method in collecting financial data of General Insurance Firms in Indonesia. All collected data in this research is originally taken from financial reports published by the Indonesian Insurance Board (DAI), called Indonesian Insurance, data was published in 1999 to 2003. Methods of analyses used in this research are financial ratios and discrimant analysis. The discriminant analysis is processed through SPSS version 12. The results indicated that there was a significant difference between well financial performances of general insurance firms and inappropriate financial performances of general insurance firms. These can be seen at F test, Sig and Wilk's Lambda. This research also could produced Z Score Model, in which could differentiate the well financial performances and inappropriate financial performances with the level of accuracy of $88 \%$. This research discovered that the ratio that could affect the well financial performances for general insurance firms in Indonesia, are ratios between Net retention premium and equity and ratio between profit (loss) after tax to average equity. This research also shown that the government policy on Finance Minister Decision No.424/KMK 06/2003 and the plan provided on Indonesian Insurance Architect, would be able to improve financial performances of general insurance firms.
\end{abstract}

Keyword : Financial ratio, financial appropriateness

\section{PENDAHULUAN}

Jumlah perusahaan perasuransian di Indonesia per 31 Agustus 2004 adalah 361 perusahaan yang memiliki izin usaha untuk beroperasi di Indonesia, terdiri atas 173 perusahaan asuransi dan reasuransi, dan 188 perusahaan penunjuang asuransi. Perusahaan asuransi dan reasuransi terdiri dari 57 perusahaan asuransi jiwa, 101 perusahaan asuransi umum, 4 perusahaan reasuransi, 2 perusahaan penyelenggara program asuransi social dan jamsostek, dan 3 penyelenggara perusahaan asuransi untuk PNS dan
TNI \& Polri. Perusahaan penunjang usaha asuransi akhir Agustus 2003 ada 188 perusahaan, terdiri dari 121 perusahaan pialang asuransi, 20 perusahaan pialang reasuransi, 27 perusahaan adjuster asuransi dan 20 konsultan aktuaria (The Directorate of Insurance, Ministry of Finance, Insurance Council of Indonesia).

Setelah krisis moneter yang terjadi pada tahun 1997, industri asuransi umum di Indonesia memperlihatkan perkembangan yang signifikan. Tabel 1 memperlihatkan data-data penting yang dapat menggambarkan perkembangan 
industri asuransi umum di Indonesia dari tahun 2011 sampai dengan tahun 2015. Terlihat bahwa premi bruto telah tumbuh sebesar $102 \%$ dalam kurun waktu tahun 2011 sampai dengan tahun 2015 Sedangkan klaim bruto hanya tumbuh sebesar $20 \%$ dalam kurun waktu yang sama. Laba industri asuransi umum tumbuh sebesar 10\% dari tahun 2011 sampai dengan tahun 2015. Sementara itu, sejak tahun 2011 sampai dengan tahun 2015, modal sendiri tumbuh sebesar $43 \%$.

Tabel 1. Data - Data Pertumbuhan Industri Asuransi Umum di Indonesia (The Directorate of Insurance, Ministry of Finance, Insurance Council of Indonesia)

\begin{tabular}{|l|r|r|r|r|r|}
\hline \multicolumn{1}{|c|}{ Keterangan } & \multicolumn{1}{c|}{$\mathbf{2 0 1 1}$} & \multicolumn{1}{c|}{$\mathbf{2 0 1 2}$} & \multicolumn{1}{c|}{$\mathbf{2 0 1 3}$} & \multicolumn{1}{c|}{$\mathbf{2 0 1 4}$} & \multicolumn{1}{c|}{$\mathbf{2 0 1 5}$} \\
\hline Premi Bruto & $6.397,5$ & $6.983,5$ & $10.330,9$ & $12.380,7$ & $12.934,0$ \\
\hline Klaim Bruto & $4.266,8$ & $3.059,6$ & $5.690,1$ & $5.173,9$ & $5.128,2$ \\
\hline Laba (Rugi) & $1.091,9$ & $1.154,0$ & $1.303,5$ & 869,1 & $1.204,3$ \\
\hline Modal Sendiri & $6.667 .573,0$ & $7.038 .740,0$ & $7.954 .967,0$ & $8.360 .659,0$ & $9.555 .782,0$ \\
\hline
\end{tabular}

Keterangan : Angka - angka pada tabel dalam jutaan rupiah kecuali angka yang menunjukan tahun.

Data-data di atas memperlihatkan bahwa industri asuransi umum masih sangat berpeluang untuk terus tumbuh. Hal ini tentunya sangat menggembirakan. Namun sebagai sebuah lembaga jasa keuangan, maka kepercayaan merupakan hal yang sangat penting untuk diperhatikan. Perusahaan Asuransi Umum yang sehat dari segi keuangan akan mudah meraih kepercayaan pasar.

Sejalan dengan perkembangan industri asuransi di Indonesia, Departemen Keuangan Republik Indonesia sebagai lembaga pengawas perusahaan asuransi dan reasuransi, memandang perlu untuk membuat aturan yang jelas mengenai kesehatan keuangan perusahaan asuransi di Indonesia. Sehubungan dengan itu, pada tanggal 30 September 2003 telah diterbitkan Keputusan Menteri Keuangan Republik Indonesia (KMK) Nomor 424 / KMK.06 / 2003 tentang Kesehatan Keuangan Perusahaan Asuransi dan Perusahaan Reasuransi. Dalam pasal 2 ayat 1 dari keputusan tersebut disebutkan bahwa Perusahaan Asuransi dan Perusahaan Reasuransi setiap saat wajib memenuhi tingkat solvabilitas paling sedikit $120 \%$ dari risiko kerugian yang mungkin timbul sebagai akibat dari deviasi pengelolaan kekayaan dan kewajiban.

Dengan demikian, ditetapkan bahwa batas tingkat solvabilitas minimum Perusahaan Asuransi dan Perusahaan Reasuransi adalah sebesar $120 \%$. Yang dimaksud dengan batas tingkat solvabilitas minimum (BTSM) adalah suatu jumlah minimum tingkat solvabilitas yang ditetapkan, yaitu sebesar jumlah dana yang dibutuhkan untuk menutup kemungkinan terjadinya risiko kerugian yang timbul akibat dari deviasi pengelolaan kekayaan dan kewajiban. Sedangkan pasal 7 ayat 1 dari KMK No, 424 / KMK.06 / 2003 disebutkan bahwa Perusahaan Asuransi dan Perusahaan Reasuransi yang tidak memenuhi ketentuan tingkat solvabilitas sebagaimana dimaksud dalam pasal 2 ayat 1 wajib menyampaikan rencana 
penyehatan keuangan yang disetujui oleh pemegang saham atau yang setara dengan itu dalam rangka memenuhi tingkat solvabilitas.

Dalam prakteknya, terdapat dua belas rasio lain yang biasa digunakan oleh Perusahaan Asuransi Umum di Indonesia dalam melakukan analisa terhadap laporan keuangan perusahaan tersebut. Adapun kedua belas rasio tersebut adalah rasio likuiditas, rasio cadangan teknis terhadap aktiva lancar, rasio cadangan teknis dan modal sendiri terhadap pendapatan premi neto, rasio investasi terhadap cadangan teknis, rasio beban klaim neto terhadap pendapatan premi neto, rasio beban terhadap pendapatan premi neto, rasio laba (rugi) setelah pajak terhadap rata - rata modal sendiri, rasio cadangan premi terhadap premi neto retensi sendiri, rasio premi neto retensi sendiri terhadap modal sendiri, pertumbuhan pendapatan premi bruto, rasio hasil underwriting terhadap pendapatan premi serta rasio hasil investasi terhadap rata-rata investasi (Biro Riset InfoBank, 2004).

Permasalahan yang coba diangkat dalam penelitian ini adalah :

1. Apakah terdapat perbedaan yang signifikan antara perusahaan asuransi umum yang sehat dengan perusahaan asuransi umum yang tidak sehat.

2. Apakah rasio (variable) pembeda tersebut merupakan rasio - rasio yang berpengaruh terhadap kesehatan keuangan Perusahaan Asuransi Umum.

\section{TELAAH LITERATUR DAN PENGEMBANGAN HIPOTESIS}

Altman (1984), mengembangkan suatu model " $Z$ Score" untuk membedakan kelompok perusahaan yang gagal (failed groups) dengan kelompok perusahaan yang berhasil (nonfailed groups). Altman melakukan survey terhadap beberapa perusahaan dari beberapa negara. Penelitian ini tidak membedakan jenis industri. Dalam penelitian ini, Altman menemukan lima rasio pembeda yang mampu membedakan kelompok perusahaan yang gagal dengan kelompok perusahaan yang berhasil (Foster, 1986). Perbedaan penelitian Altman dengan penelitian yang penulis lakukan adalah pada penelitan ini, penulis focus hanya pada industri asuransi umum di Indonesia. Sedangkan kesamaannya terletak pada usaha untuk menentukan variable variable yang mampu membedakan kelompok-kelompok yang diobesrvasi.

Salusra Satria (1994) melakukan penelitian dengan menguji rasio - rasio EWS (Early Warning System) untuk perusahaan asuransi kerugian di Indonesia, dengan menggunakan metode Multiple Discriminant Analysis. Rasio - rasio EWS yang digunakan adalah rasio - rasio EWS yang diadaptasi dari NAIC (National Association of Insurance Commisioners) yang merupakan lembaga yang membantu pemerintah Amerika Serikat dalam mengawasi kegiatan perasuransian di negara tersebut.

Dalam penelitiannya, Salusra menemukan sembilan rasio dari empat belas rasio yang diuji, yang merupakan rasio terpenting dalam menentukan kesehatan keuangan perusahaan asuransi kerugian di Indonesia. Kesembilan rasio tersebut adalah agents balance to surplus, likuiditas, biaya manajemen, tingkat kecukupan dana, beban klaim, solvency margin ratio, pengembalian investasi, dan cadangan teknis. (Salusra Satria, 1994).

Perbedaan utama dengan penelitian yang penulis lakukan adalah pada rasio - rasio yang digunakan. 
Seperti yang telah dijelaskan pada bab I, rasio - rasio yang digunakan dalam penelitian ini adalah rasio - rasio yang biasa digunakan oleh Perusahaan Asuransi Umum di Indonesia dalam menganalisa laporan keuangannya. Namun demikian ada beberapa rasio yang sama - sama digunakan seperti rasio likuiditas, beban klaim dan rasio pengembalian investasi. Selain itu periode waktu yang digunakan juga sangat jauh berbeda. Salusra Satria menggunakan periode waktu tahun 1984 sampai dengan tahun 1988. Sedangkan penulis menggunakan periode waktu tahun 1999 sampai dengan tahun 2003 yaitu periode yang dapat disebut periode pasca krisis moneter. Kesamaan penelitian ini dengan penelitian yang dilakukan Salusra Satria adalah terletak pada penggunaan analisa diskriminan sebagai alat untuk menetukan rasiorasio yang paling berpengaruh terhadap kinerja keuangan perusahaan asuransi umum di Indonesia.

\section{Rasio - Rasio Keuangan Perusahaan Asuransi Umum di Indonesia}

Penelitian ini menggunakan dua belas rasio yang sudah dibakukan dalam melakukan analisa laporan keuangan perusahaan asuransi umum di Indonesia (Biro Riset InfoBank, 2004). Berikut ini interpretasi atas masing - masing rasio tersebut.

\section{Rasio : Likuiditas}

Rasio ini digunakan untuk melihat kemampuan aktiva (aktiva lancar dan Investasi) perusahaan dalam memenuhi kewajibannya. Semakin besar rasio ini menunjukkan kemampuan perusahaan yang semakin baik dalam memenuhi kewajibannya.

Rasio : Cadangan Teknis / Aktiva Lancar

Rasio ini digunakan untuk melihat kecukupan cadangan teknis terhadap kekayaan lancarnya. Rasio yang lebih besar dari $100 \%$ menunjukkan bahwa kewajiban (dalam neraca, cadangan teknis dicatatkan pada sisi kewjiban) perusahaan sudah jauh lebih besar. Tentu saja hal ini akan mempersulit perusahaan dalam memenuhi kewajibannya.

Rasio : Cadangan Teknis + Modal Sendiri / Pendapatan Premi Netto

Rasio ini menunjukan besarnya dana yang dimiliki perusahaan dalam mengantisipasi kemungkinan terjadinya klaim yang timbul dari pendapatan premi yang diraih.

Rasio : Investasi / Cadangan Teknis

Rasio ini menunjukkan kemampuan perusahaan dalam memproduktifkan cadangan teknis menjadi investasi. Semakin besar rasio tersebut berarti perusahaan mempunyai kemampuan yang baik dalam memanfaatkan cadangan teknis ke dalam portofolio investasinya.

\section{Rasio : Beban Klaim Netto /} Pendapatan Premi Netto

Rasio ini menunjukkan kemampuan premi netto yang dihasilkan perusahaan dalam menutupi beban klaim yang ada. Rasio ini sering juga disebut sebagai "claim ratio". Selain itu rasio ini juga dapat digunakan untuk menunjukan kemampuan perusahaan dalam mengelola risiko (risk management). Semakin besar rasio ini menunjukkan bahwa perusahaan kurang berhati - hati dalam menerima risiko yang ditransfer dari pemegang polis (tertanggung).

\section{Rasio : Beban / Pendapatan Premi Netto}

Rasio ini menunjukkan kemampuan perusahaan dalam melakukan effisiensi operasional. Rasio ini memperlihatkan apakah premi yang dihasilkan perusahaan mampu menutupi biaya biaya yang dikeluarkan untuk menghasilkan premi dan klaim yang harus dibayarkan kepada tertanggung. Semakin kecil rasio ini menunjukkan 
bahwa perusahaan mampu mengelola dengan baik operasionalnya, yang pada gilirannya akan menghasilkan laba.

Rasio : Laba (Rugi) Setelah Pajak / Rata-Rata Modal Sendiri

Rasio ini menunjukkan kemampuan perusahaan dalam menghasilkan laba relative terhadap modal sendiri. Semakin besar rasio ini menunjukkan bahwa perusahaan mampu menggunakan modalnya dalam menghasil return bagi pemilik modal. Rasio yang baik adalah rasio yang lebih besar dari return yang diperoleh dari investasi terhadap obligasi pemerintah.

Rasio : Cadangan Premi / Premi Netto Retensi Sendiri

Rasio ini digunakan untuk mengetahui bagian dari premi risiko sendiri yang disahkan sebagai cadangan. Standar terbaik untuk rasio ini adalah minimal $40 \%$ sesuai dengan ketentuan pemerintah.

Rasio : Premi Netto Retensi Sendiri / Modal Sendiri.

Rasio ini menunjukkan kekuatan modal sendiri terhadap premi risiko yang ditanggung sendiri. Semakin kecil rasio ini menunjukkan bahwa perusahaan tidak banyak melakukan praktik usaha asuransi. Sebaliknya, rasio yang terlalu besar dapat memberikan kesan bahwa perusahaan kurang hati - hati dalam menjalankan bisnisnya. Standar yang diperbolehkan untuk rasio ini adalah maksimal 300\% sesuai dengan peraturan yang ditetapkan oleh pemerintah.

\section{Rasio : Perubahan Pendapatan Premi Bruto}

Rasio perubahan ini digunakan untuk mengukur perkembangan pendapatan premi bruto yang sebanding. Rasio ini dapat digunakan untuk melihat pertumbuhan bisnis perusahaan. Semakin besar rasio ini berarti bisnis perusahaan semakin bertumbuh dengan baik.

\section{Rasio : Hasil Underwriting / Pendapatan Premi Neto}

Rasio ini disebut rasio underwriting (Salusra Satria, 1994). Rasio ini mengukur tingkat keuntungan dari usaha murni asuransi. Rasio underwriting yang kecil mengindikasikan ketidakmampuan perusahaan dalam mengelola risiko.

Rasio : Hasil Investasi / Rata - Rata Investasi 2 Tahun

Rasio ini disebut juga rasio pengembalian investasi (Salusra Satria, 1994). Rendahnya rasio menunjukkan ketidakmampuan perusahaan dalam mengelola portofolio investasinya.

\section{Tingkat Solvabilitas}

Solvabilitas didefenisikan sebagai kemampuan perusahaan dalam memenuhi kewajibannya (Fraser and Ormiston, 2001). Dalam berbagai referensi, solvabilitas biasa juga disebut dengan rasio likuiditas yang didefenisikan sebagai perbandingan antara aset lancar dengan kewajiban lancar (Fraser and Ormiston, 2001 dan Brigham and Ehrhardt, 2002). Dalam industri asuransi di Indonesia, khususnya asuransi umum, solvabilitas mempunyai pengertian yang berbeda. Solvabilitas merupakan kemampuan perusahaan (jumlah dana yang disisihkan) dalam rangka menghadapi risiko kerugian yang mungkin timbul sebagai akibat dari deviasi dalam pengelolaan kekayaan dan kewajiban (Salusra Satria dan Dermawan Sebayang, 2005).

\section{BTSM}

Batas Tingkat Solvabilitas Minimum (BTSM) adalah suatu jumlah minimum tingkat solvabilitas yang ditetapkan yaitu sebesar jumlah dana yang dibutuhkan untuk menutup 
risiko kerugian yang mungkin timbul sebagai akibat dari deviasi dalam pengelolaan kekayaan dan kewajiban (Salusra Satria dan Dermawan Sebayang, 2005).

\section{Kerangka Pikir}

Gambar 2 menyajikan kerangka pikir penelitian ini. Untuk keperluan penelitian ini, perusahaan asuransi umum di Indonesia di bedakan menjadi dua kelompok, yaitu kelompok satu adalah Perusahaan Asuransi Umum yang sehat, yaitu yang mempunyai rasio BTSM $>=120 \%$ per akhir Desember 2003. Sedangkan kelompok dua adalah Perusahaan Asuransi
Umum yang tidak sehat, yaitu yang mempunyai rasio BTSM $<120 \%$ per akhir Desember 2003. Pengelompokan ini mengacu pada Keputusan Menteri Keuangan No. 424 / KMK. 06 / 2003. Terhadap kedua kelompok ini, dilakukan perhitungan rasio keuangan dengan menggunakan dua belas rasio yang sudah dipilih. Kemudian terhadap keduabelas rasio ini dilakukan analisa diskriminan untuk menemukan rasio rasio yang berpengaruh terhadap kinerja keuangan masing - masing kelompok.

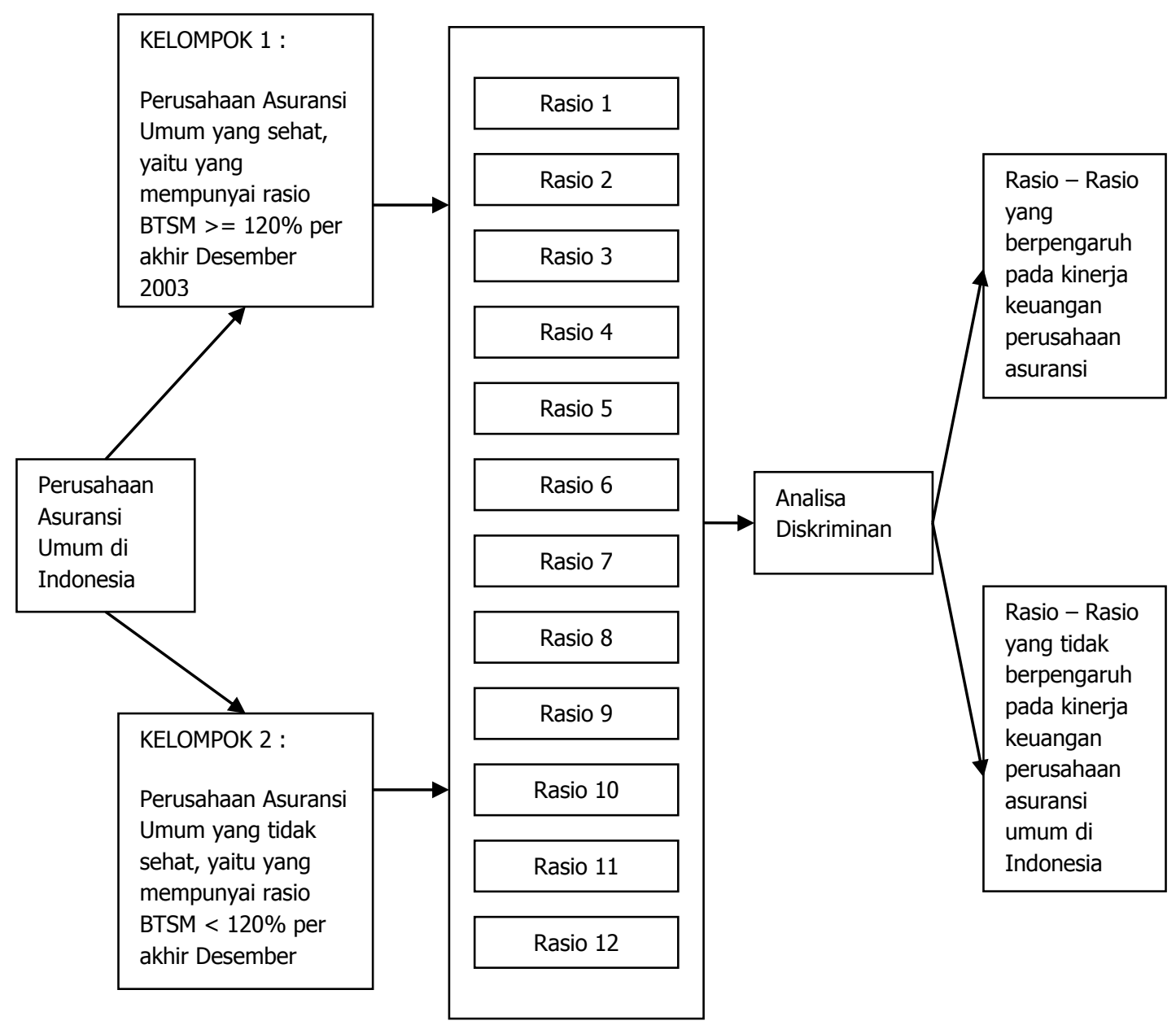

Gambar 2. Kerangka Pikir

\section{Keterangan :}

Rasio 1 : Likuiditas

Rasio 2 : Cadangan Teknis / Aktiva Lancar 
Rasio 3 : Cadangan Teknis + Modal Sendiri / Pendapatan Premi Neto

Rasio 4 : Investasi / Cadangan Teknis

Rasio 5 : Beban Klaim Neto / Pendapatan Premi Neto

Rasio 6 : Beban / Pendapatan Premi Neto

Rasio 7 : Laba (Rugi) setelah Pajak / Rata - Rata Modal Sendiri

Rasio 8 : Cadangan Premi / Premi Neto Retensi Sendiri

Rasio 9 : Premi Neto Retensi Sendiri / Modal Sendiri

Rasio 10: Pertumbuhan Pendapatan Premi Bruto

Rasio 11: Hasil Underwriting / Pendapatan Premi Neto

Rasio 12: Hasil Investasi / Rata - Rata Investasi 2 Tahun

\section{Hipotesis}

Dalam penelitian ini, hipotesa yang penulis ajukan adalah :

1. Bahwa dari dua belas rasio yang digunakan dalam penelitian ini, hanya ada beberapa rasio yang mampu membedakan Perusahaan Asuransi Umum yang sehat dengan Perusahaan Asuransi Umum yang tidak sehat.

2. Bahwa dari beberapa rasio yang mampu membedakan Perusahaan Asuransi Umum yang sehat dengan Perusahaan Asuransi Umum yang tidak sehat tersebut, tidak semuanya dapat merupakan rasio yang berpengaruh terhadap kesehatan keuangan Perusahaan Asuransi Umum di Indonesia.

\section{METODE PENELITIAN}

Penelitian dilakukan pada kantor Asosiasi Asuransi Umum di Indonesia (AAUI) yang berlokasi di Jakarta. AAUI merupakan lembaga yang berada di bawah naungan Dewan Asuransi Indonesia atau Insurance Council of Indonesia (DAI). Dalam penelitian ini, penulis menggunakan metode penelitian survey. Survey yang dilakukan bertujuan untuk mencari data-data tentang Perusahaan Asuransi Umum di Indonesia. Selain itu dalam survey ini juga dilakukan diskusi terbatas dengan beberapa pihak. Dalam penelitian ini, populasi adalah seluruh Perusahaan Asuransi Umum di Indonesia yang terdaftar pada Departemen Keuangan Republik
Indonesia per akhir tahun 2003. Dengan demikian populasi penelitian sebanyak 104 perusahaan. Sampel yang digunakan dalam penelitian ini adalah seluruh Perusahaan Asuransi Umum di Indoenesia yang terdaftar sepanjang periode pengambilan data (tahun 1999 sampai dengan tahun 2003).

Perusahaan Asuransi Umum yang digunakan sebagai sample adalah seluruh perusahaan yang masih beroperasi secara terus menerus pada periode pengambilan data, yaitu pada tahun 1999 sampai dengan tahun 2003. Dengan demikian, Perusahaan Asuransi Umum yang baru berdiri pada tahun 1999 keatas tidak dapat digunakan sebagai sample. Demikian juga Perusahaan Asuransi Umum yang sudah tidak lagi beroperasi antara tahun 1999 sampai dengan tahun 2003 juga tidak dapat digunakan sebagai sample. Jadi sampel dalam penelitian ini sebanyak 72 perusahaan yang terdiri dari 11 perusahaan dengan rasio BTSM < 120\% (kelompok Perusahaan Asuransi Umum yang sehat) dan 61 perusahaan dengan rasio BTSM >= 120\% (kelompok Perusahaan Asuransi Umum yang tidak sehat).

\section{Defenisi Operasional}

1. Perusahaan asuransi umum disebut juga dengan perusahaan asuransi kerugian (non life insurance) seperti yang dimaksud di dalam UU No.2 tahun 1992 tentang Usaha Perasuransian. 
2. BTSM (Batas Tingkat Solvabilitas Minimum) adalah suatu jumlah minimum tingkat solvabilitas yang ditetapkan, yaitu sebesar jumlah dana yang dibutuhkan untuk menutup kemungkinan terjadinya risiko kerugian yang timbul sebagai akibat dari deviasi pengelolaan kekayaan dan kewajiban (Keputusan Menteri Keuangan No. 424 / KMK.06 / 2003). BTSM sering juga disebut dengan RBC (Risk Based Capital).

3. Likuiditas dihitung dengan menggunakan formula berikut :

Likuiditas $=$ (Jumlah Aktiva Aktiva Tetap) / Kewajiban

4. Cadangan teknis dihitung dengan menggunakan formula berikut :

Cadangan Teknis $=$ Cadangan Premi + Cadangan Klaim

5. Cadangan premi sering juga disebut dengan PYBMP (premi yang belum merupakan pendapatan). PYBMP atau cadangan premi dihitung dengan menggunakan metode persentasi agregat dari premi tanggungan sendiri, yang besarnya biasanya $40 \%$ dari premi tanggungan sendiri.

6. Cadangan klaim sering juga disebut dengan EKRS (estimasi klaim retensi sendiri). Estimasi klaim retensi sendiri (cadangan klaim) dibentuk berdasarkan taksiran jumlah kewajiban yang menjadi tanggungan sendiri sehubungan dengan adanya klaim yang masih dalam proses penyelesaian termasuk klaim yang terjadi namun belum dilaporkan.

7. Yang termasuk dalam aktiva lancar adalah kas dan bank, piutang premi, piutang reasuransi serta piutang hasil investasi.

8. Yang dimaksud dengan modal sendiri adalah jumlah equity (modal) seperti yang tercantum dalan neraca perusahaan.

9. Pendapatan premi neto diperoleh dari premi penutupan langsung dan premi penutupan tidak langsung dikurangi komisi, bagian reasuransi dan kenaikan cadangan premi.

10. Yang dimaksud dengan premi penutupan langsung (direct business) adalah premi yang diperoleh dari tertanggung ataupun dari perantara (intermediary).

11. Yang dimaksud dengan premi penutupan tidak langsung (indirect business) adalah premi yang diperoleh dari sesama perusahaan asuransi.

12. Investasi yang dimaksud di sini seperti yang tercantum dalam neraca pada sisi aktiva.

13. Beban klaim neto diperoleh dari klaim penutupan langsung dan klaim penutupan tidak langsung dikurangi bagian reasuransi dan penurunan cadangan klaim

14. Yang dimaksud dengan klaim penutupan langsung adalah klaim yang timbul akibat penutupan asuransi yang berasal dari tertanggung dan perantara.

15. Yang dimaksud dengan klaim penutupan tidak langsung adalah klaim yang timbul akibat penutupan asuransi yang berasal dari sesama perusahaan asuransi.

16. Yang dimaksud beban disini adalah total biaya - biaya yang dikeluarkan perusahaan, yaitu beban klaim, komisi, beban operasional dan beban pajak.

17. Yang dimaksud dengan rata - rata modal sendiri adalah penjumlahan antaran modal sendiri pada tahun berjalan dengan modal sendiri tahun sebelumnya, dibagi dua.

18. Premi neto retensi sendiri diperoleh dari premi penutupan langsung dan premi penutupan 
tidak langsung dikurangi dengan komisi dan bagian reasuransi.

19. Perubahan pendapatan premi bruto adalah perubahan perolehan premi penutupan langsung dan premi penutupan tidak langsung setelah dikurangi komisi dibayar pada tahun berjalan terhadap perolehan premi penutupan langsung dan premi penutupan tidak langsung setelah dikurangi komisi dibayar tahun sebelumnya.

20. Hasil underwriting (underwriting surplus) adalah keuntungan atau kerugian yang diperoleh dari usaha murni asuransi. Hasil underwriting diperoleh dari pendapatan premi neto dikurang beban klaim neto dan biaya adjuster (bila memang diperlukan).

21. Hasil investasi adalah total pengembalian (return) yang diperoleh dari investasi yang dilakukan perusahaan.

22. Untuk kepentingan penelitian ini, yang dimaksud dengan Perusahaan Asuransi Umum yang sehat adalah Perusahaan Asuransi Umum yang memiliki rasio BTSM $>=120 \%$. Dan sebaliknya, Perusahaan Asuransi Umum yang tidak sehat adalah Perusahaan Asuransi Umum yang memiliki rasio BTSM < $120 \%$.

\section{HASIL PENELITIAN DAN PEMBAHASAN}

\section{Variabel Pembeda}

Salah satu indikator yang digunakan dalam mengelompokkan Perusahaan Asuransi Umum yang tidak sehat dan yang sehat rasio BTSM, yakni Perusahaan Asuransi Umum yang memiliki rasio BTSM kurang dari 120 persen dikelompokkan kedalam Perusahaan Asuransi Umum yang tidak sehat dan Perusahaan Asuransi Umum yang memiliki rasio BTSM lebih besar atau sama dengan 120 persen dikelompokkan sebagai Perusahaan Asuransi Umum yang sehat.

Sementara itu, untuk mengetahui variabel pembeda antara kelompok perusahaan yang sehat dan yang tidak sehat dapat digunakan pendekatan statistik model Multiple Discriminant Analysis. Berdasarkan perhitungan yang dilakukan sebagaimana dapat dilihat pada tabel 10 berikut.

Tabel 10. Test of Equality of Group Means

\begin{tabular}{|c|c|c|c|c|c|}
\hline & Wilks' Lambda & $\mathrm{F}$ & df1 & $\mathrm{df} 2$ & Sig. \\
\hline $\mathrm{X} 1$ & .996 & .259 & 1 & 70 & .612 \\
\hline $\mathrm{X} 2$ & .983 & 1.209 & 1 & 70 & .275 \\
\hline $\mathrm{X} 3$ & .999 & .066 & 1 & 70 & .798 \\
\hline $\mathrm{X} 4$ & 1.000 & .009 & 1 & 70 & .925 \\
\hline $\mathrm{X} 5$ & .995 & .337 & 1 & 70 & .563 \\
\hline $\mathrm{X} 6$ & .996 & .256 & 1 & 70 & .614 \\
\hline $\mathrm{X} 7$ & .783 & 19.454 & 1 & 70 & .000 \\
\hline $\mathrm{X} 8$ & .984 & 1.169 & 1 & 70 & .283 \\
\hline $\mathrm{X} 9$ & .858 & 11.615 & 1 & 70 & .001 \\
\hline $\mathrm{X} 10$ & .997 & .220 & 1 & 70 & .641 \\
\hline $\mathrm{X} 11$ & .995 & .337 & 1 & 70 & .563 \\
\hline $\mathrm{X} 12$ & .941 & 4.360 & 1 & 70 & .040 \\
\hline
\end{tabular}


Sumber : Hasil perhitungan

Tabel 10 digunakan untuk menentukan variabel - variabel pembeda dari dua belas variabel yang dianalisa. Dalam menentukan variabel pembeda, yang perlu diperhatikan dari Tabel 10 adalah nilai Wilk's Lambda, $F$ dan Sig. Variabel yang memiliki nilai $F$ terbesar dan lebih besar dari 1 serta nilai Wilk's Lambda terkecil adalah variabel yang memiliki kemampuan pembeda terbesar. Secara teoritis dikatakan bahwa untuk mengetahui perbedaan dalam setiap kelompok yakni Perusahaan Asuransi Umum yang sehat dengan Perusahaan Asuransi Umum yang tidak sehat dapat digunakan angka Wilk's Lambda. Jika angka Wilk's Lambda mendekati angka 0, maka variabel (rasio) yang digunakan pada setiap kelompok cenderung berbeda. Sedangkan uji $\mathrm{F}$ mensyaratkan bahwa jika Sig < 0,05 berarti ada perbedaan antar kelompok, dan jika Sig > 0,05 berarti tidak ada perbedaan antar kelompok (Santoso, 2004). Berdasarkan Tabel 10 tersebut terlihat angka Wilk's Lambda berkisar antara $0.783-1.000$, dimana variabel X7 merupakan variabel yang angka Wilk's Lambdanya paling kecil sedangkan variabel X4 merupakan variabel yang angka Wilk's Lambdanya paling besar. Dengan demikian terlihat bahwa variabel $\mathrm{X} 7$, X9 dan X12 merupakan variabel - variabel yang memiliki kemampuan pembeda terbesar. Variabel X2 dan X8 memang memiliki nilai $\mathrm{F}$ lebih besar dari 1, namun nilai Sig-nya lebih besar dari 0,05 , sehingga dengan demikian kedua variabel tersebut tidak dapat dijadikan sebagai variabel pembeda.

Hal tersebut berarti bahwa ketiga variabel tersebut yakni X7 (Laba Rugi setelah Pajak / Rata - Rata Modal Sendiri), X9 (Premi Netto Retensi Sendiri / Modal Sendiri) dan X12 (Hasil Investasi / Rata - Rata Investasi 2 Tahun) bagi Perusahaan Asuransi Umum yang tidak sehat dan Perusahaan Asuransi Umum yang sehat berbeda secara nyata sementara variabel lainnya tidak berbeda secara nyata. Atau dengan kata lain, rasio laba (rugi) setelah pajak terhadap rata - rata modal sendiri, rasio premi neto retensi sendiri terhadap modal sendiri, rasio hasil investasi terhadap rata - rata investasi 2 tahun, merupakan rasio rasio yang mampu membedakan perusahaan asuransi umum yang sehat dengan perusahaan asuransi umum yang tidak sehat.

Tabel 11 menyajikan rasio rasio yang dapat menjadi rasio pembeda dan rasio - rasio yang tidak dapat menjadi rasio pembeda serta kriteria penentuannya.

Tabel 11. Rasio Pembeda dan Rasio Tidak Pembeda

\begin{tabular}{|l|l|l|l|}
\hline \multicolumn{1}{|c|}{ Rasio } & \multicolumn{1}{c|}{ Nilai F } & Wilk's Lambda & Sig \\
\hline \multicolumn{4}{|c|}{ Rang Dapat Menjadi Variabel Pembeda } \\
\hline $\begin{array}{l}\text { Rasio X7 : } \\
\text { Laba (rugi) setelah pajak / Rata - rata modal sendiri }\end{array}$ & 19.454 & 0.783 & 0.000 \\
\hline $\begin{array}{l}\text { Rasio X9: } \\
\text { Premi neto retensi sendiri / Modal sendiri }\end{array}$ & 11.615 & 0.858 & 0.001 \\
\hline $\begin{array}{l}\text { Rasio X12: } \\
\text { Hasil investasi / Rata - rata investasi 2 tahun }\end{array}$ & 4.360 & 0.941 & 0.040 \\
\hline \multicolumn{4}{|l|}{ Rasio yang Tidak Dapat Menjadi Variabel Pembeda } \\
\hline $\begin{array}{l}\text { Rasio X1 : } \\
\text { Likuiditas }\end{array}$ & 0.259 & 0.996 & 0.612 \\
\hline Rasio X2: & 1.209 & 0.983 & 0.275 \\
\hline
\end{tabular}




\begin{tabular}{|l|l|l|l|}
\hline Cadangan teknis / aktiva lancar & & & \\
\hline $\begin{array}{l}\text { Rasio X3 : } \\
\text { Cadangan teknis + modal sendiri / pendapatan } \\
\text { premi neto }\end{array}$ & 0.066 & 0.999 & 0.798 \\
\hline $\begin{array}{l}\text { Rasio X4 : } \\
\text { Investasi / Cadangan teknis }\end{array}$ & 0.009 & 1.000 & 0.925 \\
\hline $\begin{array}{l}\text { Rasio X5 : } \\
\text { Beban klaim neto / pendapatan premi neto }\end{array}$ & 0.337 & 0.995 & 0.63 \\
\hline $\begin{array}{l}\text { Rasio X6 : } \\
\text { Beban / Pendapatan premi neto }\end{array}$ & 0.26 & 0.996 & 0.614 \\
\hline $\begin{array}{l}\text { Rasio X8 : } \\
\text { Cadangan premi / Premi neto retensi sendiri }\end{array}$ & 1.169 & 0.984 & 0.283 \\
\hline $\begin{array}{l}\text { Rasio X10: } \\
\text { Pertumbuhan pendapatan premi bruto }\end{array}$ & 0.220 & 0.997 & 0.641 \\
\hline $\begin{array}{l}\text { Rasio X11: } \\
\text { Hasil underwriting / pendapatan premi neto }\end{array}$ & 0.337 & 0.995 & 0.563 \\
\hline
\end{tabular}

Sumber : Hasil perhitungan

Rasio yang dapat menjadi variabel pembeda adalah rasio yang memenuhi semua kriteria berikut :
a. Mempunyai nilai $\mathrm{F}>1$
b. Mempunyai nilai sig $<0.05$
c. Memiliki angka Wilk's Lambda terkecil.

Dengan demikian rasio - rasio $\mathrm{X} 1, \mathrm{X} 2$, $\mathrm{X} 3, \mathrm{X} 4, \mathrm{X} 5, \mathrm{X} 6, \mathrm{X} 8, \mathrm{X} 10$ dan X11 tidak dapat menjadi varibel pembeda karena tidak memiliki kemampuan untuk membedakan kelompok secara nyata.

Dari sisi manajemen keuangan, tidak terpilihnya rasio - rasio $\mathrm{X} 1, \mathrm{X} 2$, $\mathrm{X} 3, \mathrm{X} 4, \mathrm{X} 5, \mathrm{X} 6, \mathrm{X} 8, \mathrm{X} 10$ dan X11 sebagai variabel pembeda dapat dijelaskan sebagai berikut. Pada tabel 3 terlihat bahwa komponen utama pendapatan adalah pendapatan premi neto. Sedangkan tingkat pengembalian terdiri dari dua komponen utama, yaitu hasil investasi dan laba (rugi). Kemampuan untuk mengembangkan bisnis secara terus menerus, yang berarti memperbesar pendapatan serta kemampuan untuk memaksimalkan tingkat pengembalian (hasil investasi dan laba) akan membawa dampak secara keseluruhan terhadap membaiknya komponen - komponen keuangan lainnya, yang ditunjukan dalam rasio - rasio $\mathrm{X} 1, \mathrm{X} 2, \mathrm{X} 3, \mathrm{X} 4$, X5, X6, X8, X10 dan X11. Sebagai contoh, rasio - rasio keuangan $\mathrm{PT}$. Asuransi Astra Buana (AAB) (lihat lampiran 1b dan lampiran 1c), seperti disajikan dalam tabel di bawah ini.

\begin{tabular}{|c|c|c|}
\hline Jenis Rasio & $\begin{array}{c}\text { Angka Rasio utk } \\
\text { PT. AAB }\end{array}$ & $\begin{array}{c}\text { Standar Industri (Sumber : Biro Riset InfoBank, } \\
\text { 2004) }\end{array}$ \\
\hline \multicolumn{3}{|c|}{ Rasio Pembeda } \\
\hline $\mathrm{X7}$ & $54 \%$ & $>=8 \%$ (juga berlaku untuk ROA) \\
\hline X9 & $198 \%$ & $<280 \%$ \\
\hline $\mathrm{X} 12$ & $13 \%$ & $>=8 \%$ \\
\hline \multicolumn{3}{|c|}{ Bukan Rasio Pembeda } \\
\hline $\mathrm{X} 1$ & $126 \%$ & $>=120 \%$ \\
\hline $\mathrm{X} 2$ & $226 \%$ & $<100 \%$ \\
\hline $\mathrm{X} 3$ & $125 \%$ & $>=100 \%$ \\
\hline $\mathrm{X} 4$ & $212 \%$ & $>=100 \%$ \\
\hline $\mathrm{X} 5$ & $52 \%$ & $<=100 \%$ \\
\hline X6 & $87 \%$ & $<=100 \%$ \\
\hline $\mathrm{X} 8$ & $41 \%$ & $>40 \%$ \\
\hline $\mathrm{X} 10$ & $28 \%$ & $>=12 \%$ \\
\hline $\mathrm{X} 11$ & $48 \%$ & $<=100 \%$ \\
\hline
\end{tabular}

(C) 2019 STIE TDN. All rights reserved

Corresponding Author: 
Terlihat bahwa rasio yang baik dari X7, X9 dan X12 pada PT. AAB memberikan dampak yang baik secara keseluruhan terhadap rasio $\mathrm{X} 1, \mathrm{X} 2$, X3, X4, X5, X6, X8, X10 dan X11.

Dengan demikian, pernyataan bahwa tujuan (goal) perusahaan adalah meningkatkan pendapatan (ini berarti mengembangkan bisnis secara terus menerus), memaksimalkan tingkat pengembalian serta tetap memperkuat modal (Brigham dan Ehrhardt, 2002), Tabel 12. Variabel Entered / Removed diperkuat dengan fakta yang ditemukan dari analisa di atas.

\section{Proses Diskriminan}

Tabel 12 menyajikan variabel mana saja dari dua belas variabel bebas yang dimasukkan (entered) dalam persamaan diskriminan. Oleh karena proses adalah stepwise (bertahap) maka akan dimulai dengan variabel yang mempunyai angka $F$ hitung (statistic) terbesar.

\begin{tabular}{|c|c|c|c|c|c|c|c|}
\hline \multirow{3}{*}{ Step } & \multirow{3}{*}{ Entered } & \multicolumn{6}{|c|}{ Min. D Squared } \\
\hline & & \multirow{2}{*}{ Statistic } & \multirow{2}{*}{$\begin{array}{l}\text { Between } \\
\text { Groups }\end{array}$} & \multicolumn{4}{|c|}{ Exact $\mathrm{F}$} \\
\hline & & & & Statistic & df1 & df 2 & Sig. \\
\hline 1 & $\mathrm{X} 7$ & 2.088 & 0 and 1 & 19.454 & 1 & 70.000 & $3.647 \mathrm{E}-05$ \\
\hline 2 & X9 & 3.280 & 0 and 1 & 15.068 & 2 & 69.000 & $3.719 \mathrm{E}-06$ \\
\hline
\end{tabular}

At each step, the variable that maximizes the Mahalanobis distance between the two closest groups is entered.

a Maximum number of steps is 24 .

b Maximum significance of $\mathrm{F}$ to enter is .05 .

c Minimum significance of $\mathrm{F}$ to remove is .10 .

d F level, tolerance, or VIN insufficient for further computation.

Sumber : Hasil perhitungan

Pada tahap pertama, angka $\mathrm{F}$ hitung variabel X7 adalah yang terbesar, yaitu 19,454. Maka pada tahap ini, variabel X7 terpilih. Pada tahap kedua, angka $F$ hitung X9 adalah kedua terbesar, yaitu 15,068. Maka pada tahap ini, variabel X9 terpilih. Jadi sampai pada tahap kedua ini telah ada dua variabel, yaitu X7 dan X9 yang dapat dimasukkan ke dalam persamaan diskriminan. Sampai dengan tahap kedua ternyata tidak ada lagi variabel yang memiliki angka $\mathrm{F}$ yang besar (lebih dari 1). Dengan demikian, proses pemilihan hanya dilakukan dalam dua tahap. Terlihat bahwa variabel X7 dan X9 mempunyai angka Sig masing masing sebesar 3,647E-05 dan 3,719E06 , yang sangat jauh di bawah 0,05 . Ini berarti kedua variabel tersebut sangat mampu membedakan kelompok Perusahaan Asuransi Umum yang sehat dengan kelompok Perusahaan Asuransi Umum yang tidak sehat. Atau dapat dikatakan bahwa variabel X7 dan X9 berpengaruh terhadap kesehatan keuangan Perusahaan Asuransi Umum.

Tabel 13 menyajikan tahapan penentuan angka signifikansi (Sig). 
Tabel 13. Wilk's Lambda

\begin{tabular}{|c|c|c|c|c|c|c|c|c|c|}
\hline \multirow[b]{2}{*}{ Step } & \multirow{2}{*}{$\begin{array}{c}\text { Number } \\
\text { of } \\
\text { Variables }\end{array}$} & \multirow[b]{2}{*}{ Lambda } & \multirow[b]{2}{*}{ Df1 } & \multirow[b]{2}{*}{ df2 } & \multirow[b]{2}{*}{ df3 } & \multicolumn{4}{|c|}{ Exact $\mathrm{F}$} \\
\hline & & & & & & Statistic & df1 & df2 & Sig. \\
\hline 1 & 1 & .783 & 1 & 1 & 70 & 19.454 & 1 & 70.000 & 3.647E-05 \\
\hline 2 & 2 & .696 & 2 & 1 & 70 & 15.068 & 2 & 69.000 & 3.719E-06 \\
\hline
\end{tabular}

Sumber : Hasil perhitungan

Wilk's Lambda pada prinsipnya adalah varians total dalam discriminant scores yang tidak bisa dijelaskan oleh perbedaan di antara kelompok kelompok yang ada (Santoso, 2004). Berdasarkan data pada Tabel 12 tersebut menunjukkan bahwa pada step (tahap) pertama jumlah variabel yang dimasukkan hanya satu yakni variabel X7 dengan angka Wilk's Lambda sebesar 0.783, yang berarti bahwa $78.30 \%$ varians tidak dapat dijelaskan oleh perbedaan antar kelompok perusahaan. Pada tahap selanjutnya dengan menambahkan variabel X9, angka Wilk's Lambda turun menjadi 0.696, dimana penurunan angka tersebut menunjukkan hal yang baik karena varians yang tidak bisa dijelaskan menjadi semakin kecil (dari $78,3 \%$ menjadi 69,6\%).

Tabel 14 menunjukkan nilai eigenvalue dan canonical corelation yang dapat digunakan untuk melihat kekuatan hubungan antara variabel bebas dan variabel terikat pada fungsi diskriminan yang dibentuk.

Tabel 14. Eigenvalues and Canonical Correlation

\begin{tabular}{|l|r|r|r|r|}
\hline Function & \multicolumn{1}{|c|}{ Eigenvalue } & \multicolumn{1}{c|}{ \% of Variance } & Cumulative \% & $\begin{array}{c}\text { Canonical } \\
\text { Correlation }\end{array}$ \\
\hline 1 & $.437(\mathrm{a})$ & 100.0 & 100.0 & .551 \\
\hline
\end{tabular}

a First 1 canonical discriminant functions were used in the analysis.

Sumber : Hasil perhitungan

Pada Tabel 14 dapat dilihat bahwa angka canonical correlation sebesar 0,551. Hal ini berarti terdapat hubungan yang cukup kuat antara variabel terpilih $\mathrm{X} 7$ dan $\mathrm{X} 9$ dengan nilai diskriminan yang ditentukan oleh dua variabel terpilih Angka eigenvalues 0,437 memperlihatkan bahwa fungsi diskriminan yang dibentuk mempunyai kemampuan yang cukup dalam membedakan kelompok.

Sementara itu untuk mengetahui hubungan (korelasi) antara variabel independen dalam hal ini rasio-rasio keuangan dengan fungsi diskriminan yang terbentuk, maka dapat digunakan struktur matriks sebagaimana dapat dilihat pada Tabel 15 berikut.

Tabel 15. Structure Matrix

\begin{tabular}{|l|r|}
\hline \multirow{2}{*}{} & \multicolumn{2}{|c|}{ Function } \\
\cline { 2 - 2 } X7 & \multicolumn{1}{|c|}{1} \\
\hline X9 & .798 \\
\hline X11(a) & -.616 \\
\hline X5(a) & .228 \\
\hline X10(a) & -.228 \\
\hline X8(a) & -.225 \\
\hline X6(a) & .121 \\
\hline X4(a) & -.113 \\
\hline
\end{tabular}

(C) 2019 STIE TDN. All rights reserved 


\begin{tabular}{|l|r|}
\hline X1(a) & .069 \\
\hline X12(a) & .068 \\
\hline X3(a) & .023 \\
\hline X2(a) & -.009 \\
\hline
\end{tabular}

Pooled within-groups correlations between discriminating variables and standardized canonical discriminant functions Variables ordered by absolute size of correlation within function.

a This variable not used in the analysis.

Sumber : Hasil perhitungan

Pada Tabel 15 terlihat bahwa hanya variabel X7 dan X9 yang mempunyai korelasi yang kuat dengan fungsi diskriminan yang terbentuk. Variabel X7 memiliki korelasi positip yang kuat (ditunjukkan dengan angka 0,798) terhadap fungsi diskriminan. Sedangkan variabel X9 mempunyai korelasi negatip yang kuat (ditunjukkan dengan angka -0,616) dengan fungsi diskriminan.

Sampai tahap ini, terlihat bahwa rasio X12 pada akhirnya tidak mampu secara signifikan menjadi rasio pembeda sekaligus rasio yang berpengaruh terhadap kesehatan keuangan perusahaan asuransi umum. Bila diperhatikan lagi laporan laba rugi seperti yang terlihat pada tabel 3, maka laba perusahaan asuransi umum dapat ditentukan sebagai berikut :

Laba $=$ Pendapatan premi neto - Beban klaim neto - Beban usaha + Hasil investasi

Dengan demikian terlihat bahwa rasio $\mathrm{X} 12$ tergantikan dengan rasio X7. Hal ini selaras dengan data yang ditunjukan oleh tabel 15. Korelasi rasio X7 jauh lebih kuat dibanding dengan korelasi rasio X12 terhadap fungsi diskriminan.

Selanjutnya berdasarkan hasil perhitungan sebagaimana terlihat pada tabel 16, dapat dibentuk fungsi diskriminan yang biasa dilambangkan dengan $\mathrm{Z}_{\text {Score }}$.
Tabel 16. Canonical Discriminant Function Coefficient

\begin{tabular}{|l|l|}
\hline \multirow{2}{*}{ X7 } & Function \\
\cline { 2 - 2 } & 1 \\
\hline $\mathrm{X} 9$ & .053 \\
\hline (Constant) & -.008 \\
\hline
\end{tabular}

Unstandardized coefficients

Sumber : Hasil perhitungan

Berdasarkan tabel 16, maka fungsi diskriminan yang dibentuk adalah sebagai berikut :

$Z_{\text {Score }}=0,151+0,053 X_{7}-0,008 X_{9}$

Fungsi diskriminan ini digunakan untuk menentukan apakah suatu Perusahaan Asuransi Umum merupakan Perusahaan Asuransi Umum yang masuk dalam kategori sehat atau kategori tidak sehat.

Oleh karena ada dua jenis kelompok (kelompok Perusahaan Asuransi Umum yang sehat dan kelompok Perusahaan Asuransi Umum yang tidak sehat), maka disebut Two-Group Discriminant, dimana grup yang satu mempunyai centroid (group means) negatif dan yang satunya lagi mempunyai centroid (group means) positip (Santoso, 2004). Tabel 17 menunjukkan besaran $Z$ yang memisahkan kedua kelompok tersebut.

Tabel 17. Function at Group Centroid

\begin{tabular}{|c|c|}
\hline \multirow[t]{2}{*}{ Ratio BTSM } & Function \\
\hline & 1 \\
\hline$<120$ & -1.534 \\
\hline$>=120$ & .277 \\
\hline
\end{tabular}

Unstandardized canonical discriminant

functions evaluated at group means

Sumber : Hasil perhitungan

Dari tabel 17 terlihat bahwa kelompok Perusahaan Asuransi Umum yang tidak sehat mempunyai centroid negatif $(Z=-$ 1,534). Sedangkan kelompok Perusahaan Asuransi Umum yang sehat mempunyai centroid positip $(Z=0,277)$. Terlihat bahwa terdapat nilai diskriminan yang 
saling tumpang tindih antara kedua kelompok. Untuk mengatasinya,diperlukan suatu nilai kritis yang disebut dengan cut off score $\left(\mathrm{Z}_{\mathrm{CU}}\right)$. Tujuannya adalah agar pengelompokkan Perusahaan Asuransi Umum menjadi kelompok sehat dan kelompok tidak sehat dapat dilakukan. Karena jumlah sampel kelompok Perusahaan Asuransi Umum yang sehat tidak sama dengan jumlah sampel kelompok Perusahaan Asuransi Umum yang tidak sehat, maka cut off score dapat dihitung dengan menggunakan persamaan berikut (Hair dkk, 1998) :

$Z_{C U}=\frac{N_{A} Z_{B}+N_{B} Z_{A}}{N_{A}+N_{B}}$

Dimana :

$\mathrm{N}_{\mathrm{A}}$ : Jumlah sampel kelompok Perusahaan Asuransi Umum yang tidak sehat (rasio BTSM $<120 \%$ )

$\mathrm{N}_{B}$ : Jumlah sampel kelompok Perusahaan Asuransi Umum yang sehat (rasio BTSM > 120\%)

$\mathrm{Z}_{\mathrm{A}}$ : Angka centroid kelompok Perusahaan Asuransi Umum yang tidak sehat (rasio BTSM $<120 \%$ )

$\mathrm{Z}_{\mathrm{B}}$ : Angka centroid kelompok Perusahaan Asuransi Umum yang sehat (rasio BTSM > 120\%)

Tabel 18.Classification Results

$$
Z_{C U}=\frac{\stackrel{\text { Jadi }}{(11)(0,277)+(61)(-1,534)}}{11+61}=-1,257
$$

Ini berarti jika suatu Perusahaan Asuransi Umum memiliki $Z_{\text {Score }}$ yang diperoleh dari persamaan 3 lebih kecil dari -1,257 maka perusahaan tersebut masuk ke dalam kelompok Perusahaan Asuransi Umum yang tidak sehat. Sebaliknya jika suatu Perusahaan Asuransi Umum memiliki $\mathrm{Z}_{\text {Score }}$ lebih besar dari -1,257 maka perusahaan tersebut masuk ke dalam kelompok Perusahaan Asuransi Umum yang sehat. Untuk menentukan tingkat ketepatan fungsi tersebut dalam mengelompokkan perusahaan asuransi berdasarkan rasio BTSM, maka dapat dihitung dengan menggunakan tabel classification results seperti pada tabel 18 berikut.

\begin{tabular}{|c|c|c|c|c|c|}
\hline & & \multirow{2}{*}{ Ratio BTSM } & \multicolumn{2}{|c|}{$\begin{array}{l}\text { Predicted Group } \\
\text { Membership }\end{array}$} & \multirow{2}{*}{ Total } \\
\hline & & & $<120 \%$ & $>=120 \%$ & \\
\hline \multirow{4}{*}{ Original } & \multirow{2}{*}{ Count } & $<120 \%$ & 8 & 3 & 11 \\
\hline & & $>=120 \%$ & 5 & 56 & 61 \\
\hline & \multirow{2}{*}{$\%$} & $<120 \%$ & 72.7 & 27.3 & 100.0 \\
\hline & & $>=120 \%$ & 8.2 & 91.8 & 100.0 \\
\hline \multirow{4}{*}{$\begin{array}{c}\text { Cross- } \\
\text { validated(a) }\end{array}$} & \multirow{2}{*}{ Count } & $<120 \%$ & 8 & 3 & 11 \\
\hline & & $>=120 \%$ & 5 & 56 & 61 \\
\hline & \multirow{2}{*}{$\%$} & $<120 \%$ & 72.7 & 27.3 & 100.0 \\
\hline & & $>=120 \%$ & 8.2 & 91.8 & 100.0 \\
\hline
\end{tabular}

a Cross validation is done only for those cases in the analysis. In cross validation, each case is classified by the functions derived from all cases other than that case.

b $88.9 \%$ of original grouped cases correctly classified.

c $88.9 \%$ of cross-validated grouped cases correctly classified.

Sumber : Hasil perhitungan

Tabel 18 menjelaskan bahwa perusahaan pada data awal (original) yang tergolong tidak sehat dan setelah klasifikasi fungsi discriminant tetap (c) 2019 STIE TDN. All rights reserved 
pada kelompok perusahaan tidak sehat adalah 8 perusahaan asuransi. Sedangkan perusahaan pada data awal (original) yang tergolong sehat dan setelah klasifikasi fungsi discriminant tetap pada kelompok perusahaan sehat adalah 56 perusahaan asuransi.

Berdasarkan hasil perhitungan sebagaimana terlihat pada tabel 18 tersebut diatas, maka diperoleh angka ketepatan prediksi fungsi discriminant sebesar 0,88 atau $88 \%$ yang diperoleh dari : $\frac{8+56}{72}$. Ini berarti bahwa ketepatan prediksi model diskriminan atau model $\mathrm{Z}_{\text {Score }}$ sangat tinggi. Oleh karena angka ketepatan tinggi, maka model diskriminan di atas (persamaan 3) bisa digunakan untuk analisis diskriminan. Atau penafsiran tentang berbagai tabel yang telah disajikan di atas valid untuk digunakan.

\section{Implikasi Terhadap Kebijakan Perusahaan}

Dari analisa di atas terlihat bahwa strategi dasar yang harus dilakukan oleh setiap perusahaan asuransi umum agar tumbuh menjadi perusahaan yang sehat dengan kinerja keuangan terbaik, adalah dengan :

1. Meraih pertumbuhan secara berkesinambungan yang disertai kemampuan yang baik dalam meretensi sendiri premi yang diterima.

2. Selalu menerapkan prinsip kehati hatian.

Strategi dasar ini tercermin dari rasio X7 dan X9. Dari tabel 20, terlihat bahwa angka untuk kedua rasio ini menunjukkan angka yang sangat baik. Beberapa kebijakan yang dapat diambil perusahaan asuransi umum sebagai implikasi dari strategi dasar tersebut adalah sebagai berikut ;

\section{Pemasaran.}

Data per 31 Desember 2003 (Dewan Asuransi Indonesia, 2003) memperlihatkan total premi neto retensi sendiri industri asuransi umum sebesar Rp 4.791.474.000.000. Kontribusi premi neto retensi sendiri untuk asuransi kendaraan bermotor sebesar Rp 2.192.092.000.000 (46\%). Kontribusi premi neto retensi sendiri untuk asuransi harta benda sebesar Rp 967.373.000.000 (20\%). Sedangkan premi neto retensi sendiri asuransi pengangkutan sebesar Rp 430.116.000.000 (9\%). Dengan demikian terlihat bahwa untuk meraih pertumbuhan premi yang baik, perusahaan asuransi umum sebaiknya memfokuskan diri untuk memasarkan asuransi kendaraan bermotor, asuransi harta benda dan asuransi pengangkutan.

Pemasaran ketiga jenis asuransi tersebut memerlukan saluran distribusi yang berbeda - beda. Pemasaran asuransi kendaraan bermotor sebaiknya menggunakan saluran distribusi agen, broker dan perusahaan pembiayaan. Asuransi harta benda (di dalamnya termasuk asuransi kebakaran) sebaiknya menggunakan perbankan sebagai saluran distribusi melalui aliansi bisnis yang saling menguntungkan. Sedangkan pemasaran asuransi pengangkutan sebaiknya menggunakan broker dan perbankan sebagai saluran distribusi.

\section{Pengendalian Risiko}

Salah satu cara yang dapat dilakukan untuk mengendalikan risiko adalah dengan melakukan diversifikasi produk. Diversifikasi produk dapat dilakukan melaui jenis perlindungan yang ditawarkan seperti Allrisk, TLO, Comprehensive, Property Allrisk, Kebakaran, Perils of the sea, Perils on the sea, dan lain - lain. Diversifikasi berdasarkan perlindungan dapat dipasarkan dalam bentuk paket. Diversifikasi produk dapat juga dilakukan berdasarkan jenis objek pertanggungan seperti mobil, sepeda motor, rumah, kantor, pabrik, rumah 
toko, angkutan darat, angkutan laut, dan lain - lain.

Selain itu, pengendalian risiko dapat dilakukan dengan cara reasuransi. Sebelum memutuskan untuk melakukan reasuransi, pertama tama yang dilakukan adalah mengidentifikasi karakteristik risiko dari setiap jenis asuransi yang dipasarkan. Identifikasi karakteristik risiko dapat dilakukan dengan menggunakan "kuadran risiko" seperti yang terlihat pada gambar 3 .

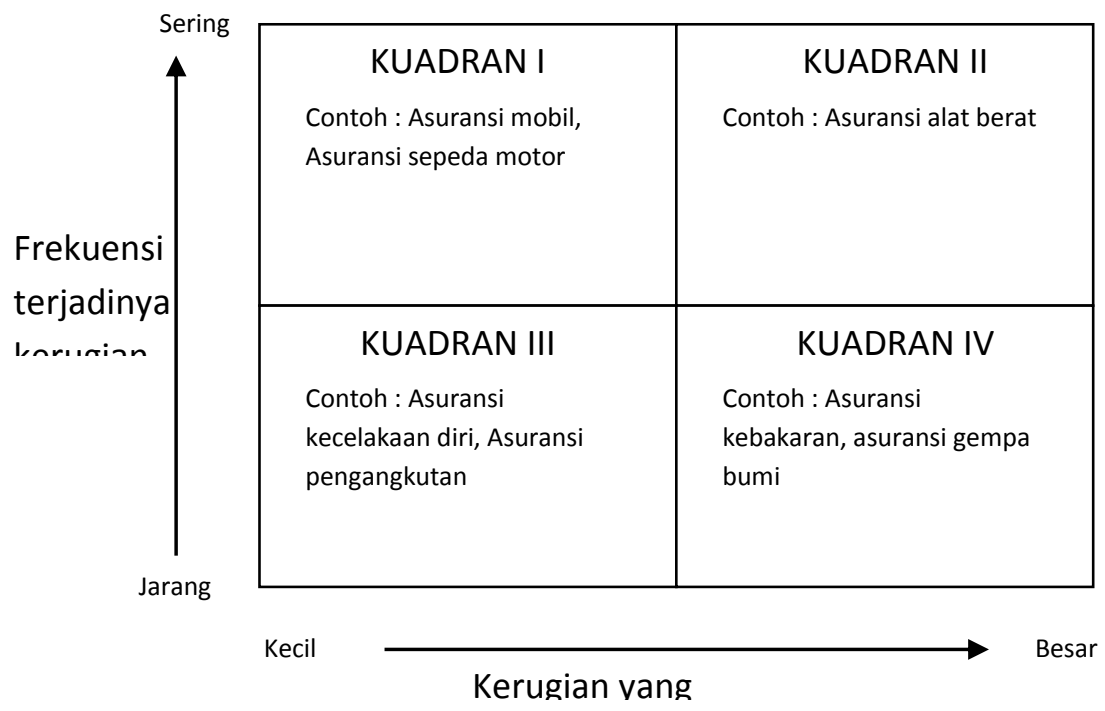

Gambar 3. Kuadran Risiko

Untuk memaksimalkan perolehan premi neto retensi sendiri sekaligus mampu mengendalikan risiko yang mungkin terjadi, sebaiknya kebijakan reasuransi hanya dilakukan untuk jenis - jenis asuransi yang masuk dalam kuadaran II dan kuadran IV.

\section{Permodalan}

Pertumbuhan premi bruto yang tinggi belum tentu secara langsung menyebabkan pertumbuhan premi neto retensi sendiri yang tinggi jika tidak diikuti dengan ketersediaan modal yang memadai. Data (lampiran 1c) memperlihatkan bahwa rata - rata pertumbuhan premi bruto (rasio X10) PT. Asuransi Tugu Kresna sebesar 78\%. Namun kemampuan PT. Asuransi Tugu Kresna dalam meretensi sendiri premi tersebut sangat rendah (terlihat bahwa rata - rata rasio X9 hanya sebesar 30\%). Hal ini disebabkan oleh modal PT. Asuransi Tugu Kresna nyaris tidak bertambah (bahkan cenderung turun). Hal yang sama terjadi pada PT. Asuransi Wanamekar Handayani. Hal yang sebaliknya dapat dilihat pada PT. Asuransi Astra Buana. Rata - rata pertumbuhan premi bruto (rasio X10) sangat baik, yaitu 28\%. Kemampuan PT. Asuransi Astra Buana dalam meretensi sendiri premi yang diterimanya juga sangat baik (rata rata rasio X9 sebesar 198\%). Hal ini disebabkan oleh pertumbuhan modal yang sangat baik (dari tahun 1999 sampai tahun 2003, secara total modal perusahaan tumbuh sebesar $171 \%$ ).

Jadi jelas terlihat bahwa agar pertumbuhan premi baru akan memberikan dampak yang baik bagi keuangan perusahaan bila diimbangi dengan pertumbuhan modal. 
Pertumbuhan modal dapat diperoleh melalui laba ditahan, penambahan modal dari investor lama serta mencari investor baru.

\section{KESIMPULAN}

Berdasarkan pembahasan yang telah dilakukan, dapat diambil kesimpulan sebagai berikut :

1. Terdapat perbedaan yang signifikan terhadap Perusahaan Asuransi Umum yang sehat dan Perusahaan Asuransi Umum yang tidak sehat. Hal ini dibuktikan pada analisis F, Sig dan Wilk's Lambda

2. Model diskriminan yang dibentuk dapat digunakan untuk menentukan perusahaan asuransi umum yang sehat dengan tingkat ketepatan sebesar $88 \%$.

3. Kebijakan pemerintah yang tertuang dalam Keputusan Menteri Keuangan No 424 / KMK.06 / 2003 dan rencana Arsitektur Perasuransian Indonesia merupakan kebijakan yang terbukti secara ilmiah mampu mendorong perusahaan asuransi umum menjadi perusahaan yang sehat. Hal terlihat dari terpilihnya rasio Premi Neto Retensi Sendiri terhadap Modal Sendiri dan rasio Laba (Rugi) setelah Pajak terhadap Rata - Rata Modal Sendiri sebagai rasio - rasio yang berpengaruh terhadap kesehatan keuangan Perusahaan Asuransi Umum di Indonesia. Oleh karenanya, kebijakan ini harus didukung penuh oleh pelaku industri asuransi umum di Indonesia.

4. Perusahaan asuransi umum yang sehat sekaligus memiliki kinerja keuangan terbaik dapat diidentifikasi dengan menggunakan model $Z_{\text {Score }}$ dan Rasio Konvensional (ROA, ROE dan Likuiditas) yang dikombinasikan dengan hasil pemeringkatan yang dikeluarkan oleh Biro Riset InfoBank.

5. Strategi dasar yang dapat digunakan agar suatu perusahaan asuransi umum menjadi sehat sekaligus memiliki kinerja keuangan yang terbaik adalah meraih pertumbuhan premi secara berkesinambungan dengan memaksimalkan kemampuan retensi sendiri serta selalu menerapkan prinsip kehati - hatian.

\section{DAFTAR PUSTAKA}

Anonim. Juni 2005. Menunggu Arsitektur Perasuransian Indonesia. Human Capital. Nomor 15. Jakarta

Biro Riset InfoBank (birI). Juli 2004. Memahami Rapor Asuransi Umum. Majalah InfoBank, No 304. Jakarta.

Brigham, Eugene F., Ehrhardt, Michael C. 2002. Financial Management. $10^{\text {th }}$ Edition. Thomson Learning. South Western.

Departemen Keuangan Republik Indonesia. 2003. Keputusan Menteri Keuangan Nomor 424 / KMK.06 / 2003 tentang Kesehatan Keuangan Perusahaan Asuransi dan Perusahaan Reasuransi. Jakarta.

Djojosoedarso, Soeisno. 2003. Prinsip - Prinsip Manajemen Risiko dan Asuransi. Penerbit Salemba Empat. Jakarta.

Foster, George.1986. Financial Statement Analysis. Second Edition. Prentice Hall

Fraser, Lyn M., Ormiston, Ailen. 2001. Understanding Financial Statement. Sixth Edition. Prentice Hall. New Jersey.

Gunanto. 2003. Asuransi Kebakaran di Indonesia. Logos. Jakarta 
Hair, Joseph. F., Anderson, Rolph. E., Tatham, Ronald. L. 1998. Multivariate Data Analysis. $5^{\text {th }}$ Edition. Prentice Hall. New Jersey

Holyoake, Julia., Weipers, Bill. 2002. Insurance. $4^{\text {th }}$ Edition. CIB Publishing. New Delhi. India.

Insurance Council of Indonesia (DAI). 1999 - 2003. Indonesian Insurance. The Directorate of Insurance, Ministry of Finance - Indonesia. Jakarta.

Lembaga Pengembangan Manajemen Asuransi. 2005. Penghitungan $R B C$ dan Pelaporan Keuangan Berdasarkan SAP. Workshop. Sekolah Tinggi Manajemen Asuransi Trisakti. Jakarta.

PT. Asuransi Adira Dinamika, 2005. Insurance. Bahan Training.

Santoso, Singgih. 2004. SPSS Statistik Multivariate. PT. Elex Media Komputindo. Jakarta

Satria, Salusra. 1994. Pengukuran Kinerja Keuangan Perusahaan Asuransi Kerugian di Indonesia. Lembaga Penerbit Fakultas Ekonomi Universitas Indonesia, Jakarta.

Satria, Salusra., Sebayang, Dermawan. 2005. Penghitungan RBC dan Pelaporan Keuangan Berdasarkan SAP. Lembaga Pengembangan Manajemen Asuransi. Sekolah Tinggi Manajemen Asuransi Trisakti. Jakata

Siamat, Dahlan. 2004. Manajemen Lembaga Keuangan. Edisi Keempat. Lembaga Penerbit Fakultas Ekonomi Universitas Indonesia, Jakarta.

Supranto, J. 2001. Statistik. Jilid 2.

Edisi Keenam. Penerbit Erlangga. Jakarta. 